DOI: $10.33067 /$ SE.4.2021.7

\author{
Özgün Erler Bayı» ${ }^{\star}$ \\ KevserMermerAkmaz ${ }^{\star \star}$

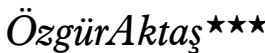

\title{
New Space: The European Union's Evolving Space Policy and Changing European Space Ecosystem
}

\begin{abstract}
Throughout the years, the identity and institutional capacity of the European Union (EU) has changed. As a global actor in international politics, the EU has perceived the need for developing a comprehensive space policy perspective. This perspective has evolved by the changing dynamics of the space ecosystem i.e., "New Space", and it is a phenomenon that consists of new business models, new technologies, new markets, new value chains, and new actors. New actors in space activities have drastically altered the dynamics of space activities. This paper aims to examine the new actors in the context of European space governance, and scrutinise the tendencies of space companies so as to develop a better understanding of the European space system. The article concludes that, being aware of the undeniable importance of space applications and the security of space systems, the EU attaches importance to catching the "New Space" trend in its governance structure and encouraging appropriate changes in the sector.
\end{abstract}

Keywords: European Space Governance, Space Policy, New Space, European Union, European Space Agency

^ Özgün Erler Bayır - Istanbul University, e-mail: ozguner@istanbul.edu.tr, ORCID: 0000-0002-5906-4362.

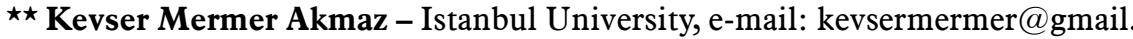
com, ORCID: 0000-0002-9537-7876.

$\star \star \star$ Özgür Aktaş - Istanbul University, e-mail: ozgur.aktas@ogr.iu.edu.tr, ORCID: 0000-0002-1232-7903. 


\section{Introduction}

Artificial intelligence, the internet of things, 5G, satellite radio systems, satellite navigation systems... space technologies have become the foundation of daily life's technologies, and space systems have become an indispensable part of social life. According to 2020 space economy data, Europe is one of the three largest space economies. The total space expenditures of the USA, China, and the EU correspond to $81 \%$ of the entire space economy. ${ }^{1}$ Until recently, while nation states had been the main actors of the space sector, the ecosystem began to change. Today, with the rapid development of technology and the increasing participation of new entrepreneurs in the space sector, the dynamics of the space ecosystem have changed. The new dynamics of the space ecosystem is simply called "New Space". Several different kinds of actors which operate space activities now have to adapt to New Space.

Europe has been, historically speaking, at the forefront of space studies. With its academic and scientific activities and its approach that supports innovation, Europe encourages cooperation in the field of space and prioritises supply chain security. As a result of institutional changes in a long and thorny process, the European Union is now a global actor in international politics. Thus, it is unthinkable for the Union to neglect the new developments concerning space. To catch new trends, the EU has adapted its policies to the new dynamics of space ecosystem. Moreover, the EU, as a transnational organisation, is a part of European space governance in cooperation with the European Space Agency (ESA) and national space agencies, meaning that EU space policies are highly inter-connected with these other actors. With New Space, space companies of different scales are added to European Space governance. To understand this new space environment, it is important to comprehend the tendencies of actors and the relations between different components of the European space ecosystem. While there are plenty of analyses on the traditional actors of European space governance, there are relatively fewer studies on New Space, space companies, and their tendencies in the sector.

This paper aims to analyse European space companies in connection with the New Space phenomenon within the context of European space governance and scrutinise the tendencies of the companies in space sectors. By doing this, the authors intend to propose a better understanding of the European space ecosystem. Moreover, this paper aims to demonstrate a genuine connection between the changing identity of the EU and

${ }^{1}$ https://www.thespacereport.org/uncategorized/global-space-economy-nears447b/ (access 20.09.2021). 
the transformation of European space governance in a way to support new actors. In accordance with these purposes, this paper is divided into three main parts. Firstly, the changing identity of the EU as a global actor will be explained by giving references to the Union's space policies. Secondly, the New Space phenomenon and the changing structure of European space governance will be examined. Last but not least, the tendencies of European space companies and new space trends will be analysed.

\section{The Changing Identity and Institutional Capacity of the EU as a Global Actor}

The EU, as a successful peace project and an entity which puts integration and unity at its centre, has become one of the strongest leading global actors in today's world. The strength of the EU stems from the fact that it is a project that has achieved a unique economic and political integration centered on peace and stability in its area.

The transformations in the international system after the Cold War undoubtedly affected the European Community, and the member countries started to take steps to make changes in the structure of the community to take a more active role in the new international system. One of the most important of these steps was the signing of an agreement on the creation of an economic and political union, which can be called a turning point for the transformation of the European Community into the "European Union", as a result of a series of meetings held in Maastricht in 1991. With the Maastricht Agreement, important decisions were taken, such as the adopting of a common currency, seeking ways to follow a common foreign and security policy, and increasing the power of the European Parliament. All the regulations and policies followed by the EU after the Maastricht Treaty must be considered as necessary steps taken in terms of the EU's global positioning and effectiveness in the international system. The strength of the integration, which was developed by the Amsterdam and Nice Treaties, took its final shape with the Lisbon Treaty in 2007. The Lisbon Treaty is one of the foremost and comprehensive reformative steps taken by the EU for its becoming a global player in the world. The Lisbon Treaty represents a crucial step towards there being more coherence in the Union's foreign and security policy, such as its aiming to be a strong and effective foreign policy actor and contributing to peace, security, and sustainable development in Europe and in the world. The EU's global role was firstly built on the aim that brings crucial values and norms to the international community. Regarding its political, economic, and normative capabilities, the EU is also holding several oppor- 
tunities that are contributing to its efforts to maintain a global-player role in world politics. However, there are some challenges for the EU in terms of consolidating its place among the other leading powers in the world, especially in foreign and security policy and economic power.

In the last 10-20 years, we have witnessed a gradual transformation in the EU in terms of both its institutional identity and its international positioning. Having successfully expanded after the Cold War, the EU has also been experiencing a deepening process in integration. The Lisbon Treaty, which followed the draft convention, is proof of this process. The treaty brought about crucial institutional changes and strengthened the supranational aspect of the EU. In this process, some challenges still exist that cannot be easily overcome, especially in the fields of common foreign and security policy. Nevertheless, the visionary policies that followed the Lisbon Treaty were intended to overcome these obstacles. In one of the main strategy documents of the EU, "Shared Vision, Common Action: a Stronger Europe, a Global Strategy for the EU's Foreign and Security Policy" (June 2016), the EU's shared interests and principles have been defined as follows:

"The European Union will promote peace and guarantee the security of its citizens and territory. Internal and external security are ever more intertwined: our security at home depends on peace beyond our borders. The EU will promote a rules-based global order with multilateralism as its key principle and the United Nations at its core. In a more complex world, we must stand united. Only the combined weight of a true union has the potential to deliver security, prosperity and democracy to its citizens and make a positive difference in the world. In a more connected world, the EU will engage with others. We will act globally to address the root causes of conflict and poverty, and to promote human rights. The EU will be a responsible global stakeholder, but responsibility must be shared. We will deepen our partnerships with civil society and the private sector as key players in a networked world. To promote our shared interests, adhering to clear principles, the EU will pursue five priorities: the security the Union, state and societal resilience to the east and south, an integrated approach to conflicts, cooperative regional orders and global governance for the 21 st century".

The EU has gone beyond national barriers without achieving a state status. It is a consequence of the initiatives that have been driven by the Member States' governments. However, especially in the last decade, sometimes the issue of sharing of national sovereignty has generated some tension inside the process of integration as "a deeper integration" is seen as the solution for most of the problems of the EU. The Union is

2 Shared Vision, Common Action: A Stronger Europe, Luxemburg, June 2016. 
facing multiple challenges in the $21^{\text {st }}$ century. Some will be solved with deeper integration, the creation of policies, and the sharing of a new level of sovereignty between the Members. Some will be temporally addressed with cooperation at a higher level. Furthermore, some of these challenges will require serious effort from the Member States. ${ }^{3}$

The attempt to create a common security policy and structure still contains challenges to be overcome. However, considerable progress has been made by the EU in its quest to become a global power. The EU is adopting a new security understanding to its strategies. The new understanding of security emphasises being more comprehensive and multilateral in the 21 st century. In this context, in addition to land-sea-and-air security, cyber security and space security are also included in the security areas. As has been explicitly stated in several policy documents over the last 20 years, this trend in the international arena is also being followed by the EU.

It is essential to catch up with the emerging space trends in order to ensure space security. In this context, cooperation structures should be established to solve issues that require joint steps regarding space, and the governance structure should be adaptive. Thanks to the inclusion of different actors, the European space sector has a dynamic structure. ${ }^{4}$ Due to the nature of space technologies, it provides a dual use in the forms of a technology that has both military utility and sufficient commercial potential to support a viable industrial base. ${ }^{5}$ Ensuring space security and sustainability is a growing challenge for the EU and other stakeholders. In addition to that, the stability of space systems is a dominant concern for all space actors. ${ }^{6}$

\section{Space in EU Documents}

The importance of space is underlined in several strategy documents of the Union. In the 2003 European Security Strategy Document "A Secure Europe in a Better World", the cosmos is only mentioned in a space-

${ }^{3}$ D. Ramiro Troitiño et al., EU in Twenty-First Century, Does Crisis Mean Opportunity?, in: The EU in the 21st Century: Challenges and Opportunities for the European Integration Process, ed. D. Ramiro Troitiño, Cham 2020, pp. 3-9.

4 N. Antoni et.al., Strategic Overview of European Space and Security Governance, in: Handbook of Space Security: Policies, Applications and Programs, ed. M. Adriaensen et.al., Springer 2020, p. 422.

5 J. Pražák, Dual-use Conundrum: Towards the Weaponization of Outer Space?, "Acta Astronautica", vol. 187/2021, pp. 397-405.

${ }^{6}$ J.J. Tortoraand, S. Moranta, European Space Security Policy: A Cooperation Challenge for Europe, in: Handbook of Space Security: Policies, Applications and Programs, ed. M. Adriaensen et.al., New York 2020, p. 449. 
assets manner for military missions and a more secure Union. Thirteen years later, in 2016, following the institutional changes which came with the Lisbon Treaty, a comprehensive policy paper was created by the EU and named "Shared Vision, Common Action: A Stronger Europe". In this document, it is emphasised that the EU has an interest in advancing "sustainable access to the global commons through open sea, land, air, and space routes", and the EU promotes the autonomy and security of their own space services. ${ }^{7}$ Moreover, concerning space security, the document stressed the importance of investing in "Intelligence, Surveillance, and Reconnaissance, including Remotely Piloted Aircraft Systems, satellite communications, and autonomous access to space and permanent earth observation". ${ }^{8}$

Looking at one of the more recent documents; "From Vision to Action: The EU Global Strategy in Practice - Three Years On, Looking Forward" (which is not a strategy document, but a document to see the strategy in practice), space is referred to in a subheading for "Securing access to routes and networks," and it is highlighted that the strategies should be operated as it was also emphasised in the 2016 Strategy Document. ${ }^{9} \mathrm{Be}-$ sides, space is considered as one of the key points for achieving resilience as fragility and conflict seem to continue in surrounding regions. Space is considered to be among the core elements of the so-called "Integrated Approach" for ensuring the resilience and security of the surroundings. In addition, the EU critically points to the reliance on space-based technologies (e.g., European Earth Observation Programme Copernicus and the Global Monitoring for Environment and Security (GMES) for the very same aim for resilience. ${ }^{10}$

In 2020, the European Commission set out the EU Security Union Strategy ${ }^{11}$ document. Aimed at protecting every citizen of the EU, the European Commission lays down 4 key strategic priorities including space and its infrastructure in the Security Union Strategy of 2020. It is also claimed that the security of those infrastructures are keys to avoiding disruption that could be observed both in physical and digital ways. The highlights are on the concept of accompanying sector-specific initiatives with those frameworks that would tackle any risk in those frameworks

7 Shared Vision, op.cit., pp. 15, 42.

8 Ibidem, p. 45.

9 From Vision to Action: The EU Global Strategy in Practice - Three years on, Looking Forward, 2019, p. 19.

${ }^{10}$ Ibidem, p. 24.

11 Communication from the Commission on the EU Security Union Strategy, $\operatorname{COM}(2020)$ 605, Brussels, 24.07.2020. 
such as space. ${ }^{12}$ It is seen that this concept was realised a year later, in 2021, with the implementation of the EU Space Programme alongside other observation programs (Copernicus), European Global Navigation Satellite System (Galileo), etc.

Associated with space security, "strategic autonomy" in space is an issue that deserves the EU's special attention. Providing critical systems and infrastructures with space-based technologies in the world requires strategic autonomy. Being aware of the importance of this issue, the EU is trying to develop policy on space. The question which needs to be asked here is: How does the EU plan to ensure its strategic autonomy in space, considering the policies of its competitors?

In 2016, the European Commission launched a "Space Strategy for Europe". This strategy document has been a special example of emphasis for 'reinforcing Europe's autonomy in accessing and using space in a secure and safe environment'. In order to ensure Europe's access to space autonomously, reliably, and cost-effectively, the European Commission is to work cooperatively with the ESA, Member States, and several stakeholders, including the private sector. ${ }^{13}$

The 2016 Space Strategy for Europe document concludes with the following statements:

"The potential of space for Europe and the world is enormous. Europe faces huge global challenges which require global responses. Europe must contribute to this collective responsibility. No single Member State can do this alone. The EU, alongside its Member states and the ESA, must act as a global stakeholder to promote and preserve the use of space for future generations". ${ }^{14}$

The USA, China, Russia, and the EU are competing with each other in different fields. For the Union, it is crucial to increase cooperation initiatives with an emphasis on multilateralism as the leading actors in the space field in order to develop space systems. Another important factor for the EU to become a major space power is comprehending the dynamics of "New Space". The next section of this paper will explain how the EU perceives the dynamics of the New Space ecosystem and how this perspective has altered European space governance.

\footnotetext{
12 Ibidem, p. 7.

13 Communication from the Commission on Space Strategy for Europe, $\operatorname{COM}(2016) 705$, Brussels, 26.10.2016, p. 8.

14 Ibidem, p. 13.
} 


\section{"New Space" and the Changing European Space Ecosystem}

In the $20^{\text {th }}$ century, space activities were one of the many aspects of superpower competition. Even though there were many examples of private initiatives to use space for commercial purposes during this century such as satellites for television broadcasting, communication, radio, etc. the primary actors of the ecosystem of space were firstly the superpowers, followed by other powerful states in international politics. In accordance with the rising needs of societies and developing technology, the space ecosystem has undoubtedly changed in various ways. One of the ways of defining the dynamics of the space ecosystem in the $21^{\text {st }}$ century is called "New Space".

Although there is no well-founded consensus on the exact definition of New Space, the term is widely used, and it is most certainly beneficial to comprehend the contemporary situation of space politics. The term unavoidably signifies the distinction between "old" and "new" space. While traditional (or old) space is mainly associated with Cold War competition and a state-centered perspective to funding and managing space activities, ${ }^{15} \mathrm{New}$ Space is not completely detached from these concepts. Besides, some features that are primarily associated with New Space are related to traditional space as well. For example, the commercialisation of space has been progressing since the 1960s, and space companies have been operating since the 1980s. Thus, the concept of New Space might be misleading until the borders of the concept are well-defined. ${ }^{16}$ There are some studies that aim to clarify the confusion of the concepts by suggesting "big space" instead of New Space. ${ }^{17}$ This study does not particularly intend to develop a well-founded definition of New Space, therefore the features of the New Space ecosystem that are most closely related to the research topic will be mentioned.

Firstly, thanks to miniaturisation technologies, electronics now have $50 \%$ or even less mass than previous iterations, meaning that fewer resources are required to launch them into space. Smaller space technologies enable new actors to be in the "space race". Secondly, New Space is characterised by the

${ }^{15}$ D. Paikowsky, What is New Space? The Changing Ecosystem of Global Space Activity, "New Space", vol. 5, no. 2/2017, pp. 1-3.

16 A. Golkar, A. Salado, Definition of New Space-Expert Survey Results and Key Technology Trends, "IEEE Journal on Miniaturization for Air and Space Systems", vol. 2, no. $1 / 2021$, p. 2.

17 G. Denisa, et al., From New Space to Big Space: How Commercial Space Dream is Becoming a Reality, “Acta Astronautica”, no. 166/2020. 
proliferation of new actors. The category of new actors includes both new nation states which have not conducted any kind of space activities before and private companies of various scales. These new actors have the potential to alter current supply chains by introducing new business models. Last but not least, in today's world, space activities are considered to be a decent way for conducting profitable business. New sectors such as space mining, space tourism, space energy are starting to be funded by private entrepreneurs and public-private partnerships (PPP).

\section{The Structure of European Space Governance}

The new space ecosystem has changed the rules of the game irreversibly. The crucial question for Europe is: How has European space governance been adapted into this new dynamic concerning space? Considering the first EU Parliament resolution on European space policy was on 17th September 1981, the EU has had its sights set high on space for a long period of time. Traditionally speaking, European space governance has a tripartite structure. It consists of the EU, the ESA, and the national space agencies of Member States. With New Space dynamics, new actors have emerged. To evince the adopting character of European space governance, firstly we will explain the tripartite structure. Then, the private sector connections of European space governance will be analysed. Last but not least, the contemporary challenges that the space sector is facing will be mentioned.

Despite the fact that the ESA was founded in 1975, and that we can track the EU's interest in space back to the 1980s, the most critical developments for European space governance occurred in the $21^{\text {st }}$ century. In 2003, the Commission launched the White Paper on Space, a document that clearly envisages the main lines of the EU's space policy. In this document, the need for cooperation with other actors is heavily and strikingly underlined. The responsibilities of stakeholders are contemplated as follows:

“(...) the European Union should have the lead responsibility for federating society's needs for space-based services relevant to EU policies and for co-ordinating their delivery, while the European Space Agency should take the lead in elaborating, proposing and developing the required solutions. (...) Member States and their relevant space/ research agencies should be associated with the revision and ultimate adoption of the European Space Programme. National space agencies and research organisations will be largely responsible for implementing the Programme's lines of action relevant to them". ${ }^{18}$

${ }_{18}$ The White Paper on Space: A New European Frontier for an Expanding Union, SEC(2003) 1249, Brussels, 11.11.2003, pp. 37-38. 
Following the White Paper, in 2004, the Framework Agreement was signed between the EU and the ESA. The intention of the agreement was to develop a coherent and progressive European space policy, and establish a common basis for mutually beneficial cooperation between partners. ${ }^{19}$ On 26th April 2007, the joint communication European space policy emphasised that without a comprehensive space strategy, Europe would become an irrelevant actor in international politics. This perspective laid the foundation of Europe's Space Policy, which was jointly drafted by the European Commission and the Director-General of the ESA on 22nd May 2007. Moreover, Article 189 of the Treaty of Lisbon specified the EU's vision on space policy and concreted the partnership with the ESA. Last but not least, the European Union Agency for Space Program (EUSPA) was established on 28th April 2021. The program is designed to enhance the competitiveness of the Union's space industry among the other aims regarding defensive and political goals. As stated several times in the establishing document of the program, cooperation with ESA plays a crucial role in achieving political, economic, and security goals for the Union. In addition, for the time being, the European Space Program underlines the need for the development of "New Space infrastructures" and to introduce specific provisions to support the European space community. ${ }^{20}$

Today, the Directorate-General for Defence Industry and Space (DEFIS) is the leading institution in the EU for the space sector and defence industry. DEFIS is responsible for conducting the EU Space program consisting of Copernicus (European Earth Observation Program), Galileo and EGNOS (European Geostationary Navigation Overlay Service). For the period of 2021-2027, the Commission has proposed a budget of $€ 16$ billion in current prices, which equals $€ 14.2$ billion in constant 2018 prices, allocated as follows: €9.7 billion for Galileo and EGNOS; $€ 5.8$ billion for Copernicus; and $€ 0.5$ billion for SSA and GOVSATCOM. ${ }^{21}$

National space agencies are another component of European space governance, and since they directly represent the interests of nation states, their active support for all the steps is absolutely required. Among the other national agencies located in Europe, four of them are relative-

19 https://www.esa.int/About_Us/Business_with_ESA/How_to_do/Space_ESA_ and_EU_sign_cooperation_agreement (access 20.09.2021).

$\overline{20}$ Regulation (EU) No. $2021 / 696$ Establishing the Union Space Programme and the European Union Agency for the Space Programme and Repealing Regulations, Brussels, 28.04.2021.

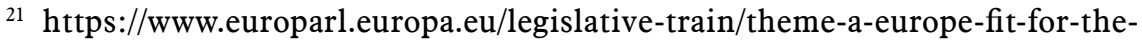
digital-age/file-mff-eu-space-programme (access 20.09.2021). 
ly more capable of conducting space activities. These are: the German, French, Italian, and UK National agencies. It is important to note that all these nations adopted official documents concerning space activities after the Treaty of Lisbon. Generally speaking, even though nation states tend to cooperate in the structure of the ESA, in the past, the EU's supranational character caused some disagreement among the national space agencies. ${ }^{22}$ While Brexit certainly mitigated the disagreements regarding EU's supranational character for EU members, it also undermined the EU's potential in space. Nevertheless, it is important to remember that, although the UK has withdrawn from the Union, it is still a member of the ESA.

As has been mentioned above, the New Space perspective has changed the dynamics of space policies and activities. Unavoidably, the traditional tripartite structure of European space governance has been adapting to this new environment via enhancing the cooperation with technology giants and promoting middle-scale and start-up space companies. Therefore, in this new picture, European space governance cannot be imagined without private sector actors. The previous statement is quite open to questions such as: How new is this phenomenon? In fact, in 2002, Galileo began being developed by the EU in cooperation with ESA, and it was the first transnational level PPP in the space industry. However, due to the lack of experience and know-how of the Commission to lead the complex PPP relations along with a miscalculation of financial conditions, in 2007, that particular PPP was terminated and GALILEO started to be entirely funded and controlled by the EU. ${ }^{23}$ Since then, the EU, the ESA, and the national space agencies have been strengthening their competence in working with private sector actors. Moreover, they have been fostering the development of space entrepreneurship by allocating tremendous resources.

To adopt the dynamics of New Space, the European Commission - in collaboration with European Investment Bank and European Investment Fund - planned to award investments in start-ups, early-stage and mature space companies via InnovFin Space Equity Pilot, the European Innovation Council Equity Fund, and the Competitive Space Start-ups for Innovation initiative (CASSINI) programs. Moreover, as a part of the new Multiannual Financial Framework for the 2021-2027 period, Horizon

22 L. Marta, National Vision for European Space Governance: Elements for a New Institutional Architecture, "Space Policy”, no. 29/2013, p. 20.

${ }^{23}$ J. Feyerer, Lessons from Galileo for Future European Public-private Partnerships in the Space Sector, in: European Space Policy: European Integration and the Final Frontier, eds. T. Hörber, P. Stephenson, New York 2016, p. 220. 
Europe, the European Defence Fund, and Invest EU programs are also designed to support companies and space-related research..$^{24}$ In addition, the ESA runs plenty of support programs that 340 start-ups benefit from. These companies are specialised in different categories such as; material and new production engineering, electronics, information and communication technologies, aeronautics, automotive, maritime $\&$ transport, etc. ${ }^{25}$ Last but not least, apart from the initiatives of the EU and the ESA, there are national programs that support investment and entrepreneurship in space-related activities. During recent years, Germany, France, Italy, Spain, and the UK have seen significant initiatives to foster private efforts towards the New Space ecosystem. ${ }^{26}$

\section{The Contemporary Situation of the Space Sector}

Despite progress on promoting space ventures and their noteworthiness, there are also some challenges that posed obstacles before the development of the European space environment. Firstly, there are some procedural challenges. In relation to their sector, some companies face long development cycles. In general, all the initiatives listed above will take years to be fully utilised for the European space ecosystem. This aside, the European space ecosystem lacks entrepreneurs with a space background and space investment expertise. ${ }^{27}$ Therefore, although the actors of the European space governance have taken remarkable steps in recent years, it could be claimed that the European space ecosystem will need more time to adapt to New Space. Secondly, the COVID-19 crisis has significantly affected all economic sectors globally, and the European space sector is certainly not free from COVID-19-related problems. Many spacerelated organisations and companies have had to measure teleworking extensively, and this process has caused productivity loss. Moreover, many space companies have also had to shut down some sites and activities. ${ }^{28}$ According to a study, 53\% of respondents from European space start-ups assessed a significant impact on their businesses due to the COVID-19 crisis. Nevertheless, it is important to note that, although investments

\footnotetext{
${ }^{24}$ ESPI Report 78 - Space Venture Europe 2020, Vienna, March 2021, pp. 2-5.

25 https://spacesolutions.esa.int/business-incubation/our-start-ups (access 20.09.2021).

${ }^{26}$ ESPI Report 78, op.cit., pp. 9-11.

27 The Future of the European Space Sector: How to Leverage Europe's Technological Leadership and Boost Investments for Space Ventures, European Investment Bank, 2019, p. 10.

${ }^{28}$ ESPI Special Report - COVID-19 and the European Space Sector, Vienna, July 2020, pp. 9-12.
} 
paused between March and June 2020, the impact of the crisis on investment was not noticeable at the end of the year. ${ }^{29}$

The use of space-based systems during the COVID-19 period provided support for the management of the crisis. The use of satellite images and navigation to analyse and follow changing situations has allowed the process to be well managed. In addition, many national space agencies and ESA have contributed to the production of materials to be used in the field of health. In the early days of the epidemic, the Leonardo S.p.A group supported the production of medical devices in Italy. Airbus, on the other hand, started to manufacture face shields and masks in all its facilities. However, disruptions occurred in existing space project programs. Science missions such as ExoMars, Mars Express, and Solar Orbiter have been delayed. Supply chains were also affected by the disruption due to the closure of border gates during the COVID-19 period. In production processes especially, there were problems in the supply of raw materials. In a macroeconomic context, changes occurred in the level of demand and in public policies and budgets. For this reason, there has been a decrease in space investment capacities. ${ }^{30}$

\section{The Tendencies of Space Companies in European Space Governance}

\section{New Space Business Sectors: Upstream and Downstream}

Space systems are the basis of technologies that are used in daily life. Many technological products that societies use to maintain their daily lives use space-based systems. Phones, communication and navigation technologies (also regional positioning and timing techs.), the internet, and all the systems that can be used connected to the internet, including payment and card systems, and satellite-based television broadcasting are all fine examples. There are several other enormous strategic usage areas of space that affect societies' daily lives, such as monitoring oceans and other geographical environments. Space technologies have also brought about the ability to monitor air pollution and climate change. Space technologies also make it possible to protect food supply chain security by comparing data from satellite images. Analysis tools and satellite-based information enables us to forecast food production. Undoubtedly, one of the most important and strategically useful areas of space-based systems

${ }^{29}$ ESPI Report 78, op.cit., p. 26.

30 ESPI Special Report - COVID-19 and the European Space Sector, op.cit., pp. 6-10. 
is military systems. The fact that space has enabled us to use such a variety of technologies and plays an important role in critical systems such as food security, climate, communication, and the military has put it on the agenda of states.

New Space activities affect space infrastructures that include upstream and downstream sectors. The upstream sector mainly covers more expensive technologies, including design and launch satellites, research and development studies, and developing space infrastructure. The downstream sector, on the other hand, mostly includes works about space-based information, observation activities, broadcasting, and communication systems. ${ }^{31}$ Data valuation is a usage area of space applications that has effects on different sectors. Evaluating the data obtained by space-based systems in many applications such as agriculture, ocean monitoring, and geographical uses gives high-value results. With a correct analysis of the data, highly accurate estimations can be made and many undesirable situations such as disasters and crises can be prevented.

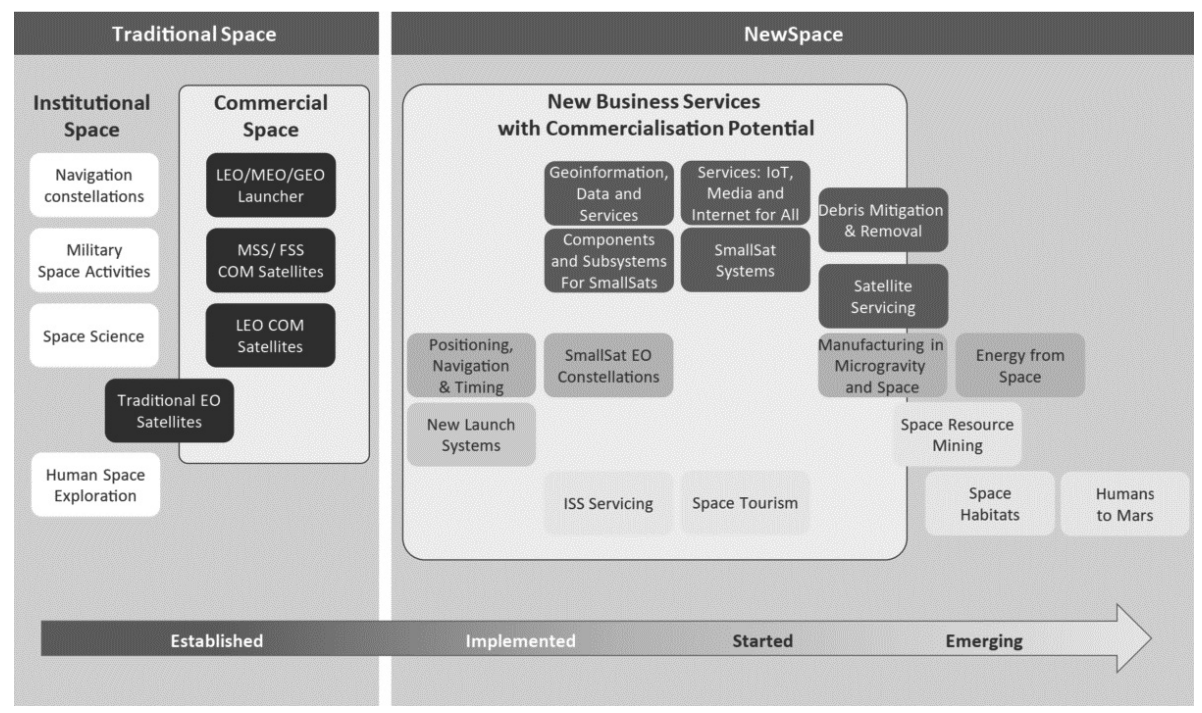

Figure1. Traditional and New Space Business Services

Source: The Future of the European Space Sector: How to Leverage Europe's Technological Leadership and Boost Investments for Space Ventures, European Investment Bank, 2019.

The New Space approach brings many trends and needs that emphasise the realisation of business and service-oriented commercial goals. These trends and needs can be categorised thus; new public schemes, new sec-

${ }^{31}$ The Future of the European Space Sector..., op.cit., p. 9. 
tor actors such as entrepreneurs, new private investment, new market areas, new solutions to new problems, and a new industrial environment. ${ }^{32}$ Technologies that can be adapted to space systems have taken part in this trend, even if they participate in non-space activities in developing new sectors and business areas. The changing nature of the sector also requires new arrangements in public mechanisms. New space programs of states or international organisations emphasise that new entrants and enterprises are the driving force of the New Space trend. Eventually, public structures will need to change and be adaptive. The upstream and downstream applications of space also create new data-based knowledge. This knowledge is mostly highly-priced and includes functional tools.

The share of cube satellites in the sector in 2016 can be examined in order to understand the impact of the New Space approach in the sector. Cube satellites account for $37 \%$ of the total number of satellites launched, but only account for $1 \%$ of total spacecraft value. For all these reasons, New Space also brings the need for an adaptive space governance system. The governance model for Europe faces new challenges because of the new investment and business-centered structure. Considering the governance of the European space policy and its relationship with the private sector, it is evident that space is also an important sector for economic growth and the creation of new economic opportunities. As well as being a strategically important area for the EU, the space field is also a key sector in scientific competition with the major powers of the world.

\section{The New Space Market and Companies in Europe}

According to a European Commission Space Sector report, between 2011-2017, New Space investments equal two-thirds of all space-related investments. With the New Space approach, the costs of production processes have decreased, and new business models have emerged. From 2000 to 2017 , space ventures attracted more than 14.8 billion euros in investment. ${ }^{33}$ In 2019 , start-up investments reached $\$ 5.7$ billion. Last year, i.e., 2020 , this figure was $\$ 3.5$ billion, the highest level of investment until that year. ${ }^{34}$ In addition, estimated investment in start-up space companies reached $\$ 7.6$ billion. ${ }^{35}$ According to the Commission's data, the sum of venture capital firms and angel investors accounts for two-thirds of

${ }^{32}$ ESPI Report 77 - “New Space in Asia - Full Report”, Vienna, February 2021, p. 1.

33 The Future of the European Space Sector, op.cit., p. 20.

${ }^{34}$ Bryce Start-up Space: Update on Investment in Commercial Space Ventures, 2020, p. iii.

35 ESPI Insights, Vienna, August 2021, p. 8. 
investments in space ventures. Venture capital firms account for $46 \%$ of start-ups in space companies, while angel investors account for $25 \%$. New Space investors in the space sector, despite being located all around the globe, are mostly to be found in the USA. The United Kingdom and Spain together are home to around $27 \%$ of all investors worldwide. ${ }^{36}$

It seems that the giant companies of Europe will maintain their weight in the field of space for a long time. Multinational companies such as Airbus, Safran, Thales Alenia Space, and AVIO operate in and have highly diverse business portfolios. In addition to these companies that dominate the space industry and the leading suppliers, there are other companies which mainly focus on certain areas in the space industry, such as SES, Eutelsat, and Arianespace. With the New Space approach, also called Space 4.0, new companies and startups such as PLD Space, Active Space Technologies, Space Structures Gmbh, and Cevotech all play a role in the commercialisation of space. ${ }^{37}$ And, in addition to the commercialisation of space, ensuring the security of the supply chain has been the main issue of the European space systems and the space sector. It is critical for the supply chain to adapt easily to changing conditions and to have an agile structure.

The traditional space supply chain mainly consists of business segments such as satellite manufacturing, launchers and the ground equipment industry, ground equipment, space exploration, and space sciences among others. Typical financing path/funding instruments for large satellite manufacturing projects, launchers, and ground equipment industries are research and development $(\mathrm{R} \& \mathrm{D})$ grants and procurements, project finance, and corporate loans. ${ }^{38}$ On the other hand, the New Space supply chain consists of business segments including energy, mining, processing and assembly, satellite services and satellite manufacturing. These business segments also have the same funding instruments with the traditional space sector. Typical financing path/funding instruments are $R \& D$ grants and procurements, venture capital, project finances, and export credit agencies. The supply chains of New Space companies mainly face some problems because of some uncertainties. Problems such as medium and long-term capital needs and the lack of balanced market potential need to be resolved. ${ }^{39}$

Achieving market balance requires a system of regular updates to regulatory provisions and frameworks rather than attempts to address new ap-

${ }^{36}$ The Future of the European Space Sector, op.cit., p. 21.

37 https://www.techforspace.com/european-space/ (access 20.09.2021).

${ }_{38}$ The Future of the European Space Sector, op.cit., p. 113.

39 Ibidem. 
plications in totality. For new applications, new regulation systems must be developed. It also requires exchanges of information between technical, economic, business, policy, and regulatory communities. ${ }^{40}$ It is understood that the importance of the changes in the space sector is emphasised in EU strategy documents, and steps have been taken in that direction. In the European Space Policy document published in 2016, it is underlined that the entrepreneurship ecosystem should be supported, and new business opportunities should be provided.

"Enabling measures and capacity building in all Member States and at European level are needed to create the right ecosystem and a favorable regulatory and business environment that incentivizes the private sector to be more risk-prone and encourages businesses to develop innovative products and services". 41

In the most recent document of the European Council, published in 2021, it is clear that the EU supports the development and entrepreneurial ecosystem in the space domain.

"The Union's space industry is already one of the most competitive in the world. However, the emergence of new players and the development of new technologies are revolutionising traditional industrial models. Therefore, for the Union to remain a leading international player with extensive freedom of action in the space domain, it is crucial that it encourages scientific and technical progress and supports the competitiveness and innovation capacity of space sector industries within the Union, in particular small and medium-sized enterprises (SMEs), start-ups and innovative businesses". ${ }^{42}$

As a result, today, space has become an area that is enriched with projects and actors whose field of activity is gradually expanding. The need to establish effective legal regulations for developing activities or to adapt existing legal regulations to new areas has emerged. Bringing sector stakeholders could be make possible those regulations and policy developments. Bringing together industry stakeholders and ensuring coordination continues to be one of the most important issues of the space governance structure. New Space activities will bring new approaches, but these approaches should encourage and facilitate innovation.

40 D.L. Oltroggeand, I. A Christensen, Space Governance in the New Space Era, "Journal of Space Safety Engineering”, no. 7/2020.

${ }^{41}$ Communication from the Commission on Space Strategy for Europe, op.cit., p. 7.

${ }^{42}$ Regulation (EU) 2021/696 of the European Parliament and of the Council establishing the Union Space Programme and the European Union Agency for the Space Programme and repealing Regulations, Brussels, 28.04.2021. 


\section{Conclusions}

Until recently, space technologies were only developed by states. However, the New Space trend has changed this fact. The traditional space system mainly focused on government-supported companies and establishments. These space actors produce and launch satellites, navigation satellite constellations, conduct military space activities, scientific space research, and human space exploration activities among others. These working areas were aimed at earning commercial revenues in a limited fashion, but, with New Space, space has become a high-potential commercialisation area. Due to the fact that doing research and development in the space sector was incredibly costly and too risky to SMEs, it prevented the private sector from entering the space sector. However, with the increase of commercial space activities within the space sector and the efforts of states to ensure the security of the supply chain, the New Space transformation has begun.

As this paper argues, the changing identity of the EU enables a comprehensive space policy. In accordance with the new space ecosystem, traditional actors of European space governance have adapted their programs in a way to support and encourage European space companies. Several grants are dedicated by the EU, the ESA, and national space agencies in order to promote European space companies on all different levels. The key factor of the European perspective on space is cooperation. As long as European space governance remains loyal to their genuine perspective, objectives that require a high level of dedication and resources such as deep space missions, exoplanet projects etc., will be achievable.

\section{References}

Antoni N., et.al., Strategic Overview of European Space and Security Governance, in: Handbook of Space Security: Policies, Applications and Programs, ed. M. Adriaensen et.al., Springer, New York 2020.

Bryce Start-up Space: Update on Investment in Commercial Space Ventures, 2020.

Communication from the Commission on Space Strategy for Europe, $\operatorname{COM}(2016)$ 705, Brussels, 26.10.2016.

Communication from the Commission on the EU Security Union Strategy, $\operatorname{COM}(2020)$ 605, Brussels, 24.07.2020.

Denisa G., et al., From New Space to Big Space: How Commercial Space Dream is Becoming a Reality, "Acta Astronautica", no. 166/2020. 
ESPI Report 77 - New Space in Asia - Full Report”, Vieanna, February 2021.

ESPI Report 78 - Space Venture Europe 2020, Vienna, March 2021.

ESPI Special Report - COVID-19 and the European Space Sector, Vienna, July 2020.

Feyerer J.,Lessons from Galileofor Future European Public-private Partnerships in the Space Sector, in: European Space Policy: European Integration and the Final Frontier, eds. T. Hörber, P. Stephenson, Routledge, New York 2016.

From Vision to Action: The EU Global Strategy in Practice - Three years on, Looking Forward, 2019. https://www.avrupa.info.tr/sites/default/files/ uploads/eu_global_strategy_2019.pdf (access 3.11.2021).

Golkar A., Salado A., Definition of New Space-Expert Survey Results and Key Technology Trends, "IEEE Journal on Miniaturization for Air and Space Systems", vol. 2, no. $1 / 2021$.

https://www.europarl.europa.eu/legislative-train/theme-a-europe-fit-forthe-digital-age/file-mff-eu-space-programme (access 20.09.2021).

https://spacesolutions.esa.int/business-incubation/our-start-ups (access 20.09.2021).

https://www.techforspace.com/european-space/ (access 20.09.2021).

https://www.thespacereport.org/uncategorized/global-space-economynears-447b/ (access 20.09.2021).

https://www.esa.int/About_Us/Business_with_ESA/How_to_do/Space_ ESA_and_EU_sign_cooperation_agreement (access 20.09.2021).

Marta L., National Vision for European Space Governance: Elements for a New Institutional Architecture, "Space Policy", no. 29/2013.

Oltrogge D.L., Christensen I.A., Space Governance in the New Space Era, "Journal of Space Safety Engineering", no. 7/2020.

Paikowsky D., What is New Space? The Changing Ecosystem of Global Space Activity, "New Space", vol. 5, no. 2/2017.

Pražák J., Dual-use Conundrum: Towards the Weaponization of Outer Space?, "Acta Astronautica", vol. 187/2021.

Ramiro Troitiño D., et al., EU in Twenty-First Century, Does Crisis Mean Opportunity?, in: The EU in the 21st Century: Challenges and Opportunities for the European Integration Process, ed. D. Ramiro Troitiño, Springer, Cham 2020.

Regulation (EU) No. 2021/696 establishing the Union Space Programme and the European Union Agency for the Space Programme and repealing Regulations (EU), Brussels, 28.04.2021.

Shared Vision, Common Action: a Stronger Europe, Luxemburg, June 2016. 
The Future of the European Space Sector: How to Leverage Europe's Technological Leadership and Boost Investments for Space Ventures, European Investment Bank, 2019.

Tortora J.J., Moranta S., European Space Security Policy: A Cooperation Challenge for Europe, in: Handbook of Space Security: Policies, Applications and Programs, ed. M. Adriaensen et al., Springer, New York 2020.

White Paper on Space: A New European Frontier for an Expanding Union, SEC(2003) 1249, Brussels, 11.11.2003. 